\title{
Financial Stability Implications of Stress Testing for Risk Taking and Credit Growth
}

\author{
Orobah Ali Barghouthi \\ Assistant Professor \\ Faculty of Business and Economics \\ Department of Banking \& Finance \\ Alquds University, Abu Dis, Palestine \\ E-mail: obargothi@hotmail.com \\ K. M. Anwarul Islam \\ Associate Professor \\ Department of Business Administration \\ The Millennium University, Dhaka, Bangladesh \\ $\mathrm{PhD}$ Candidate \\ University of Selangor, Malaysia \\ E-mail: ai419bankingdu@gmail.com
}

Received: August 17, 2020

Accepted: August 30, 2020

Online Published: September 22, 2020

doi: I0.4628I/amfbr.v5i2.778

URL: https://doi.org/I0.4628I/amfbr.v5i2.778

\begin{abstract}
This paper examined the literature on financial stability implication of stress testing for risk-taking and credit growth in banks. Macro prudential considered one of the most stress testing tools by Applying countercyclical Macro prudential tools to build up capital buffers in good times that can be run down during bad times. But to improve timing, monitories authorities may need to develop a comprehensive framework to monitor Macro prudential conditions and establish appropriate warning and trigger thresholds. Regarding scope, they examine the entire financial system. This entity contributes to fire sales whose default has follow-on effects, or which can exacerbate a credit crunch that is included. Liability Considerations contain a Scale of wholesale funding that is run-prone is paramount. Capital adequacy depends on the health of the overall financial system. For asset Considerations, the test indicates whether the financial system is vulnerable to deleveraging that might amplify adverse shocks, at the end authorities' development guidance about whether to close a bank and when to sell its assets to maximize taxpayer recovery. We have concluded that the financial stability implications of stress tests for risk-taking and credit growth among banks are the following: A reduction in credit is a feature on stress tests. Post-crisis reforms traded the expectation of lower credit growth for reducing the probability that the larger banks would fail. This has a high negative impact on the economy. Higher capital requirements for the larger banks have prompted a reduction in the supply of credit, especially to riskier borrowers. Smaller banks have increased their share of local market-wide lending, and larger businesses have seen quite generous credit availability in bond and leveraged loan markets. Consider the structure of the financial system and its complexity long the levels of economic integration and openness.
\end{abstract}

Keywords: Financial Stability, Stress Testing, for Risk-Taking, Credit Growth.

\section{Introduction: Importance of Stress Testing}

Financial stability refers to the robustness of the financial system to external shocks. It provides the endogenous, the dependence on collective behaviour, and the nature of financial distress. It describes financial stability in terms of resilience to shocks originating within the financial system or the vulnerability to financial distress in response to normal-sized shocks rather than large shocks. (Galati and Moessner, 20I I) 
Financial stability provides sufficient assurance that the efficiency of intermediation between the supply and demand of funds will not be significantly affected by adverse events. Financial stability is an end and also a means of guaranteeing a suitable financial environment and achieving sustained and balanced economic growth in both industrialized countries and emerging economies (Lee, Gaspar, and Villaruel, 2017).

Stress tests are major post-crisis innovations in supervision. The stress tests help prevent a repeat of the financial crisis by requiring banks to hold enough capital to continue to lend a hypothetical severe macroeconomic recession and to demonstrate strong risk management practices for capital planning. But stress tests are only one of the several reforms that are working in that direction which includes increases in capital requirements, new rules requiring banks to hold ample liquidity, and derivative market reforms.

One of the stress tests includes Macro prudential tools. Applying countercyclical Macro prudential tools to build up capital buffers in good times can be run down during bad times. To improve timing, authorities need to develop a comprehensive framework to monitor Macro prudential conditions and establish appropriate warning and trigger thresholds.

\begin{tabular}{ll}
\hline Purpose & Limit the likelihood and costs of aggregate fire sales, credit crunches, and systemic defaults \\
\hline Scope & $\begin{array}{l}\text { Examines the entire financial system. The entity that contributes to fire sales, whose default has } \\
\text { follow-on effects, or which can exacerbate a credit crunch should be included }\end{array}$ \\
\hline Liability Considerations & $\begin{array}{l}\text { The scale of wholesale funding that is run-prone is paramount. Capital adequacy depends on } \\
\text { the health of the overall financial system }\end{array}$ \\
\hline Asset Considerations & $\begin{array}{l}\text { The test indicates whether the financial system is vulnerable to deleveraging that might amplify } \\
\text { adverse shocks. }\end{array}$ \\
\hline Output & $\begin{array}{l}\text { Develop guidance about whether to close a bank and when to sell its assets to maximize } \\
\text { taxpayer recovery }\end{array}$ \\
\hline
\end{tabular}

Figure I. Elements of a Macro prudential Stress Test

Source: Greenlaw, Kashyap, Schoenholtz, and Shin (2012)

Macro stress tests enable economies to assess how the financial sector as a whole responds to significant shocks such as interest rate and exchange rate movements. The Table shows the essential elements of a stress test. There is a need to incorporate general equilibrium dimensions where the outcome depends not only on the size of the shock and buffers of individual institutions but also on their behavioural responses and interactions with each other and other economic agents (Lee, Gaspar, and Villaruel, 2017).

Through Macro tests, interventions by regulators are drafted and implemented. However, it remains that these tests are posted on crisis interventions. The limitation is that regulators will know if the stress tests contribute to sound judgment only after the crisis.

Three categories of Macro prudential policy instruments:

- Reduce risk from excessive credit or credit growth; authorities can apply credit controls-such as caps on the loan-tovalue ratio, caps on the debt-to-income ratio, caps on foreign currency lending, and ceilings on credit or credit growth.

- Constrain funding or liquidity risks, liquidity-related instruments include limits on net open currency positions or currency mismatches, limits on maturity mismatches, and reserve requirements.

- Build sufficient buffers to withstand the cycle, capital-related tools can include counter-cycle capital requirements, time-varying/dynamic positioning, and restrictions on profit distribution (Lee, Gaspar and Villaruel 2017).

\begin{tabular}{lll}
\hline Policy Area & Primary Objective & Financial Stability Objective \\
\hline Prudential & Limit distress of individual institutions & Address systemic Risk (Cross-section over time) \\
\hline Monetary & Stabilize Prices & $\begin{array}{l}\text { Lean against boom or bust cycles in credit and } \\
\text { asset prices }\end{array}$ \\
\hline Exchange rate & Stabilize Exchange Rate & Reduce capital flow volatility \\
\hline Fiscal & Manage Demand counter-cyclically & $\begin{array}{l}\text { Maintain fiscal buffers that allow a response to } \\
\text { financial system stress }\end{array}$ \\
\hline
\end{tabular}

Figure 2. Towards a Global Financial Stability Framework Source: Hannoun (2010) 
Although these are not the only options, the simplified tale by Hannoun can be used as a guide in dealing with a financial stability objective vis-à-vis policy area. It remains that there is a need to reduce risk from excessive credit growth, constrain liquidity risk in reserve requirements and currency positions, and provide buffers to withstand shocks in the financial cycle.

\section{Financial Stability Implications of Stress Testing}

The stability of the financial system as a whole hinge essentially on the banking system; and a mainstay of efficiency in channeling the flow of saving between investors and savers within the banking sector is the existence of prudential regulation and adequate supervision that adequately complement each other; the former should provide the basis and the appropriate legal structure so that credit institutions can accurately assess the financial risks they incur. The latter must ensure that banks observe the rules, standards, and codes of prudence that provide them with appropriate levels in the key variables underpinning and ultimately, determining their financial condition (profitability and solvency).

The financial sector is examined as a whole to evaluate the stability of the financial system. Detection of vulnerable parts of the financial industry and their attachment to economic development provides the possibility to reduce risks and to strengthen the resilience of the financial sector against negative shocks impacts. Stress tests are a rough estimation of a portfolio transformation due to changes in risk factors (Stankova, 20I4).

Stress testing is an approach to gauge the impact of a large shock on financial soundness and market functioning. Stress testing has the potential to support Macro prudential policy in the design, calibration, and assessment of the impact of Macro prudential tools (Constancio, 2017).

Regular stress testing should provide a more reliable and accurate assessment of the possible impact of adverse shocks in the form of extreme movements in variables liable to affect the economic setting and the main determinants of the stability, and therefore the soundness of the financial system.

To address excessive credit growth and leverage, the countercyclical capital buffer may be used to measure resilience in banks and to contribute to curbing excessive credit growth. The loan-to-value and loan-to-income cap may be used to measure the resilience of borrowers and banks to mitigate pro-cyclicality mortgage credit (Lee, Gaspar, and Villaruel, 2017).

In a study conducted in the United States, the impact of the Federal Reserves' stress tests on the lending of US Bank Holding Companies. The study concluded that there is no systematic evidence in favour of the risk mitigation hypothesis. The capital gap is not constraining bank loan growth or causing banks to tighten their lending standards. Growth differences were driven largely by credit quality and by other factors beyond the stress tests such as loan demand (Basset and Berrospide, 2018)

More capital is associated with higher loan growth. Increased level of capital and the higher capital buffers brought by the post-crisis regulatory reform, which makes banks safer, more resilient, put banks in a better position to lend more (Basset and Berrospide, 2018).

Two hypotheses were considered. The risk mitigation hypothesis is where additional capital required by the stress tests causes banks to reduce their risk-taking activities by tightening their lending standards and decreasing credit supply. The risk facilitation hypothesis is where higher capital buffers resulting from the stress tests make banks more resilient and thus put them in a better position to loosen their lending standards and take more risks by increasing their lending (Basset and Berrospide 2018).

The progressive implementation of stress tests as a toll complementing traditional supervisory practices is making them increasingly valuable to financial authorities in monitoring and safeguarding the stability of the economic environment. The increasing use of stress tests highlights the need to establish basic principles and guidelines providing for a systematic ap proach to them that are rigorous and straightforward (Rodriguez, Trucharte, and Marcelo, 2018).

The possible deficits of stress tests may be seen when it selects stress scenarios in a way that might leave many dangerous scenarios and thus create an illusion of safety, which might consider highly implausible scenarios and thus trigger a false alarm. Stress tests should include tools to analyze systemic risk arising from the interaction of banks with each other and with the markets (Breuer and Summer, 2018).

Disclosure of stress-test results facilitates the coordination of risk decisions among banks by providing information about the likelihood of a bailout. The results may make risk decisions in the banking industry more extreme (Corona, Nan, and Zhang, 2019)

\begin{tabular}{lll}
\hline Stress test result & Likelihood of a Bailout & Level of Risk \\
\hline The small number of low-type banks & Low likelihood of a bailout & Low level of risk \\
\hline A large number of low-type banks & High likelihood of a bailout & $\begin{array}{l}\text { Aggravates bank's excessive risk- } \\
\text { taking }\end{array}$ \\
\hline
\end{tabular}

Figure 3. Disclosure of stress-test results

Source: Kohn and Liang (2019) 
If absent stress tests low-type banks would coordinate on an equilibrium in which they take low risk, then the disclosure of the test result can induce them to coordinate instead on an equilibrium in which they take a high risk. This forces the regulator to ban some banks from investing, which in turn leads to a welfare loss compared to the no-stress-test scenarios, because, absent stress tests, the banned banks would have generated a positive social surplus. Stress tests provide the regulator with information about banks' type and allow the regulator to fine-tune intervention policy to optimally depend not only on the individual but also on the aggregate stress-test outcomes. Therefore, conducting stress tests yields the social benefit of allowing the regulator to both intervene selectively and discipline the risk decisions of un-intervened banks (Corona, Nan, and Zhang 2019).

\section{Conclusion}

The financial stability implications of stress tests for risk-taking and credit growth among banks are the following:

A reduction in credit is a feature of stress tests. Post-crisis reforms traded the expectation of lower credit growth for reducing the probability that the larger banks would fail. This has a high negative impact on the economy. borrowers.

Higher capital requirements for the larger banks have prompted a reduction in the supply of credit, especially to riskier

Smaller banks have increased their share of local market-wide lending, and larger businesses have seen quite generous credit availability in bond and leveraged loan markets.

Consider the structure of the financial system and its complexity long the levels of financial integration and openness.

\section{References}

Basset, W., \& Berrospide, J. (2018). Impact of Post Stress Tests Capital on Bank Lending. Research.

Breuer, T., \& Summer, M. (2018). Systematic Systemic Stress Tests. Oesterreichische Nationalbank.

Constancio, V. (2017). Macroprudential stress-tests and tools for the non-bank sector. ESRB Annual Conference. Frankfurt.

Corona, C., Nan, L., \& Zhang, G. (2019). The Coordination Role of Stress Tests in Bank Risk-Taking. SSRN.

Galati, G., \& Moessner, R. (20I I). Macroprudential Policy- A Literature Review. Bank for International Settlements.

Greenlaw, D., Kashyap, A. K., Schoenholtz, K. L., \& Shin, H. S. (2012). Stressed out: Macroprudential principles for stress testing. Chicago Booth Research Paper, (12-08).

Hannoun, H. (2010, February). Towards a global financial stability framework. In Speech at the 45th SEACEN Governors' Conference, Siem Reap province, Cambodia (pp. 26-27).

Kohn, D., \& Liang, N. (2019). Understanding the effects of bank stress tests: A Q\&A. Brookings.

Lee, M., Gaspar, R., \& Villaruel, M. L. (2017). Macroprudential Policy Framework in Developing Asian Economies Market. Asian Development Bank.

Rodriguez, A., Trucharte, C., \& Marcelo, A. (2018). Stress Tests and their contribution to financial stability. Journal of Banking Regulation, 65-81.

Stankova, L. (20I4). Macro Stress Tests and their use in the analysis of financial stability and creating the business strategy. Researchgate.

\section{Copyrights}

Copyright for this article is retained by the author(s), with first publication rights granted to the journal. This is an open-access article distributed under the terms and conditions of the Creative Commons Attribution license (http://creativecommons.org/licenses/by/4.0/). 